\title{
Analysis of Educational Problems and Biology Learning in Senior High School in Kerinci Regency
}

\author{
Tomi Apra Santosa ${ }^{1 *}$, Lufri $^{1}$, Zulyusri $^{1}$ \\ ${ }^{1}$ Department of Biology Education, Universitas Negeri Padang \\ Jln. Prof. Dr. Hamka Air, no.1 Air Tawar Barat, Padang, Indonesia \\ *email: santosatomiapra@gmail.com
}

\section{Article History}

Received: 6 January 2021

Revised: 5 April 2021

Accepted: 19 April 2021

Published: 30 June 2021

\section{Key Words}

Education;

Learning;

School.

\begin{abstract}
The purpose of this study was to determine the cause of high school biology education and learning in Kerinci Regency. This type of research is qualitative with a case study. Data comes from observations, interviews, and documentation. The results of the study concluded that SMA Negeri 12 Kerinci faces learning probabilities and biology education, namely the lack of biology laboratory facilities and infrastructure, lack of computers to carry out national exams, and the lack of students who are active in the learning process of biology SMA Negeri 4 Kerinci facing learning problems and biology education as minimal management of school facilities and infrastructure and the lack of educational media in the learning process of biology.
\end{abstract}

\section{INTRODUCTION}

In the era of the industrial revolution, the 5.0 society of the Indonesian state experienced quite advanced developments in the fields of education and learning. Progress in education and learning is an important role in improving Human Resources (HR) in Indonesia (Naldi, 2019). The Human Development Index (HDI) of the Indonesian Society has increased from 71.39 in 2018 to 71.92 in 2019 (Badan Pusat Statistik, 2019). The increasing is the success in fixing the realm of education. Education is one of the social activities that is very important to promote and improve and prepare for the development of national resources in the present and future (Hasan, 2012; Okra, 2019; Sugiarto, 2017). Thus, education is indispensable in developing public knowledge (Rahmawati ,2014).

Learning is the interaction between teachers and students and students with their environment that can motivate them to learn (Effendi, 2013). In the learning process, it is not just the delivery of information from teachers to students (Ernawati, et.al., 2016).

Therefore, teachers and students are people who play a role in the success or failure of learning goals. The improvement of various aspects also influenced learning objectives such as curriculum, facilities and infrastructure and the selection of learning methods (Irfan,2019; Lalawi,et.al., 2017). The teacher should master the learning method before carrying out the teaching and learning process.

The weakness of learning and education is teaching and learning activities that teachers and students apply in the classroom (Wati, et.al., 2006). The government must be able to optimize this quality through improvements and reforms in all fields of education (Rasyid, 2014). If we pay attention to the very high role of world education in overcoming educational problems (Mohammed \& Ahmed, 2014). Therefore, it is necessary to have an interaction mechanism to collaborate between the government, teachers and students in overcoming this problem (Risi, 2018). 
Jambi is a province on the island of Sumatra. Jambi Province has 9 districts and 2 municipalities. In addition, the Human Development Index (HDI) continues to increase every year from 65,39 in 2010 to 71,26 in 2019 (Badan Pusat Statistik, 2019). This increase makes Jambi province able to compete in the national arena.

Kerinci is a district in the province of Jambi which has the second highest Human Development Index (HDI) after the city of Jambi (Badan Pusat Statistik, 2019). Kerinci has a Human Development Index (HDI) of 70.59 (Badan Pusat Statistik, 2019). Therefore, Kerinci Regency has a quality level of education and learning. However, besides having excellent quality education and learning, there are still schools that do not have facilities that support a supportive teaching and learning process.

Research by Priyayi (2018) states that biology teacher learning problems can be in groups of four kinds, namely problems relating to students, learning materials facilities and infrastructure, and family conditions students. Research by Mutiara (2015) that the problem of education in Indonesia is divided

Into seven, namely low physical means, teacher quality, teacher welfare, achievement students, opportunities for fair education, the relevance of education, and the cost of education. Research by Syafni (2013) states that high learning problems experienced by students in learning skills and less interest in student learning to consult $\mathrm{BK}$ teacher. Based on the above problem, the research aims to describe the problems education and biology learning in high school in Kerinci Regency.

\section{METHOD}

This research is a qualitative research with a case study method. Qualitative research is a way of explaining the understanding of a person or group regarding social or humanitarian problems (Creswell, 2009). Data obtained by observation, interviews, and documentation. The research subjects came from teachers and students at SMA Negeri 12 Kerinci and SMA Negeri 4 Kerinci. The data validity technique is as triangulation technique.
Data were analyzed by reducing data, presenting data, and drawing conclusions.

\section{RESULTS AND DISCUSSION}

\section{Educational and Learning Problems in SMA Negeri 12 Kerinci}

Based on research conducted by SMA Negeri 12, Kerinci found problems or problems in education and learning. Education is a part of community activity and the embodiment of the nation's ideals to advance the nation's future (Hidayatullah \& Arifin, 2012). Learning is one gateway to educate the lives of the nation's children in fostering more mature patterns of thinking and behavior. Learning in schools should be able to please teachers and students in carrying out learning and teaching activities (Rizqon, 2020; Santosa et al., 2020). Learning and teaching is an important essence that a student must need to gain knowledge. However, obstacles or problems in education or learning hinder the implementation of the teaching and learning process in schools.

SMA Negeri 12 Kerinci is a public school in Siulak Tenang Village, Gunung Kerinci District, Kerinci Regency which has accreditation. This school is experiencing problems in education and learning. In education, SMA Negeri 12 Kerinci faces problems, namely First, the lack of facilities and infrastructure for the science laboratory and computers for implementing the ComputerBased National Examination. Both schools and the government must immediately address laboratory facilities and infrastructure in particular. Thus, the principal is expected to improve the facilities and infrastructure (Megasari, 2014). Educational facilities and infrastructure are tools and materials that teachers and students can directly use in schools. Educational infrastructure is something that is not directly used by students and teachers, one of which is the laboratory room (Kurniawati et al., 2013; Tanggela, 2013; Santosa et al., 2021).

The laboratory is a space used by students and teachers to carry out scientific innovations. Completeness of laboratory facilities and infrastructure can affect the smooth learning process of students in innovating (Darmastuti, 2014). The 
development of students 'mindsets through scientific innovation in providing laboratory facilities, one of which increases scientific sense or students' curiosity about phenomena that occur in nature. According to Simatupang (2013) there are 4 reasons to strengthen the role of laboratories in schools, namely science practicum to increase student motivation, increase students' ability to experiment, a place for scientific innovation, and support learning (Simatupang \& Sitompul, 2013). Thus, the government and schools must take an important role in the effective management of laboratory facilities. For laboratory management, it is necessary to look at aspects of management, organization, implementation and evaluation, layout, equipment, and administration (Rahmiyati, 2008).

Computers are information and communication technology tools used in direct data processing. The computer is a tool for presenting data quickly and automatically (Hanafri et al., 2019). This tool is a school facility and infrastructure that is very important to support the implementation of teaching and learning activities in schools. For students, computers can provide benefits for completing all learning tasks. However, computers are currently used to carry out the national exams that we now know as UNBK. This exam is an examination using a computer ( Santi \& Prajana, 2018). To achieve excellent results, it requires adequate facilities and equipment as a computer provider. If a school has provided the means and infrastructure, it will bring significant benefits to students and teachers who carry out UNBK. The advantage of UNBK is the ease in carrying out administration and assessment (Chendrasari et.al, 2019). This policy provides solutions for teachers and students in facing national exams ((Maulida et al., 2019). For this reason, we immediately resolved the provision of computers in schools in order to produce quality education in SMA Negeri 12 Kerinci.

Second, the problem at SMA Negeri 12 Kerinci in learning is that students are less active in the teaching and learning process. We need student activeness when there is a reciprocal relationship in learning. If the learning is passive students and the teacher is more dominant in explaining, then there are learning objectives that are not well achieved.
The activeness of students can increase their performance in school (Achdiyat, 2016). Teachers must be able to arouse student activeness or enthusiasm for learning through innovative learning methods or models. Teachers must adjust active learning methods so that students are motivated to be active in the classroom (Rizal, 2018).

Active learning is a way out in increasing student activity in class. Active learning is a learning model that can become active learning students, with this the teacher as a facilitator in learning while students must be active, innovative, and can take advantage of all learning facilities (Eliham, 2018; Asiah, 2017; Santosa et al., 2021). However, students actively respond quickly to the subject that the teacher has given. To encourage passive students, the teacher can apply methods such as the teacher explaining the learning method given by the teacher, which is expected to provide motivation to be active in learning, and the teacher provides rewards or gifts to students (Komariah \& Sundayana, 2017).

\section{Educational and Learning Problems in SMA Negeri 4 Kerinci}

Research conducted at SMA N 4 Kerinci found problems or problems in education and learning. The educational problems found are: First, the lack of management of facilities and infrastructure in schools. Facilities and infrastructure are the most important elements for improving the teaching and learning process in schools (Bancin, 2017). In school, students will be motivated to learn if the management and variety of facilities and infrastructure are well organized. The purpose of planning is to more effectively channel the learning process in order to achieve predetermined educational goals (Ellong, 2007). Improving the management of facilities and infrastructure in schools is the duty of the school principal. The principal is the person who is first and foremost in control of the school to manage all the existing facility in the school (Saifuddin et al., 2019).

School facilities and infrastructure are very important in increasing student competence. The facilities and infrastructure in schools have good management, so the competence of students in learning will increase (Pandriana, et.at.,2017). For that, it is necessary 
to do careful planning. The steps that can be taken in managing the managerial facilities and infrastructure are management, organizing, procurement, inventory, storage, maintenance, and deletion (Tri Firmansyah,et.al., 2018). Thus, besides these steps, it is necessary to have proper care. Maintenance is assigning work to achieve predetermined goals, or as a process in making a decision that can be carried out in the present and future according to the needs of the institution (Setyaningih, 2018).

Second, the learning problem found in SMA Negeri 4 Kerinci is the lack of development of instructional media by teachers. The general teacher still uses conventional learning media. Learning media is a way to convey information from the teacher (sender) to students (recipients) in carrying out teaching and learning activities (Tafonao, 2018). Learning media is very influencing student learning activities. Teachers must be able to take advantage of technology to create media that can foster student interest and learning outcomes. So with that, the teacher must pay attention to the factors in media selection. Things that influence teachers in using learning media are learning objectives, student behavior, types of student responses to learning, place, and learning reach (Abidin, 2016).

Improving the quality of teachers in developing instructional media can be done by increasing teacher competence. Teachers have four competencies in carrying out learning, namely personal, pedagogical, social, and professional competencies (Roza, 2020). Professional competencies, namely the four competencies that are indispensable for designing or learning media that are attractive to students. Professional competence is the teacher's ability to know science and technology (Roza, 2020; Cut Fitriani,et al.,2017).

\section{CONCLUSION}

From the above research it can be concluded that SMA Negeri 12 Kerinci faces problems in learning and biology education, namely the lack of biological laboratory facilities and infrastructure, lack of computers to carry out national exams, and the lack of Students who are active in the learning process of biology and SMA Negeri 7 Kerinci face learning and education problems as a lack of management of school facilities and infrastructure and a lack of educational media in the biology learning process

\section{REFERENCES}

(BPS), B. P. S. (2019). Badan Pusat Statistik (pp. 1-8).

Achdiyat, M. (2016). Prestasi belajar matematika ditinjau dari kepercayaan diri dan keaktifan siswa di kelas. Jurnal Formatif, 6(1), 50-61.

Chendrasari W.O, Christine Natalia, M. W. I. (2019). Pendampingan Persiapan Ujian Nasional Berbasis Komputer . Jurnal Bakti Masyarakat Indonesia, 2(1), 155161.

Darmastuti, H. (2014). Kualitas Pembelajaran Pada Jurusan Teknik Komputer Dan Informatika Di Smk Negeri 2 Surabaya. Jurnal Inspirasi Manajemen Pendidikan, 3(3), 9-20.

Effendi, M. (2013). Integrasi Pembelajaran Active Learning dan Internet-Based Learning dalam Meningkatkan Keaktifan dan Kreativitas Belajar Mukhlison Effendi. Nadwa | Jurnal Pendidikan Islam, 7(2), 283-306.

ELIHAM, S. S. M. M. E. (2018). Strategi Pembelajaran Aktif Dalam Meningkatkan Motivasi Belajar Pkn Peserta Didik. MAHAGURU: Jurnal Pendidikan Guru Sekolah Dasar, 7(1), 30-32.

Hanafri, M. I., Iqbal, M., Prasetyo, A. B., \& Pembelajaran, A. P. M. (2019). Perancangan Aplikasi Interaktif Pembelajaran Pengenalan Komputer Dasar Untuk Siswa Sekolah Dasar Berbasis Android. JURNAL SISFOTEK GLOBAl, 9(1), 87-92.

Hasan, S. H. (2012). Pendidikan Sejarah Untuk Memperkuat Pendidikan KarakteR. Paramita, 22(1), 81-95.

Henia Wati1, Abdulkadir Rahardjanto1, A. M. H. (2016). Penerapan Kerangka Rancangan Tandur Dalam Model Pembelajaran Snowball Throwing Untuk Meningkatkan Hasil Belajar Ipa Smpn 03 Candipuro Lumajang. JURNAL PENDIDIKAN BIOLOGI INDONESIA, 
I(1), 109-123.

Hidayatullah, A., \& Arifin, A. (2012). The Implementation Of Multicultural Education In The Educational Practices In Indonesia . Jurnal Pembangunan Pendidikan: Fondasi Dan Aplikasi IMPLEMENTASI, 1(1), 72-82.

Irfan, M. (2019). Pengaruh Penerapan Metode Resitasi Terhadap Hasil Belajar Kognitif Siswa SMA. BIOMA, 1(01), 47-55.

Khaira Maulida1, W. W. (2019). Upaya Yang Dilakukan Sekolah di Daerah Terpencil Menghadapi Kebijakan Ujian Nasional Berbasis Komputer (UNBK). 2(3), 243250.

Kurniawati, P. I., Sayuti, S. A., \& N. (2013). Manajemen Sarana Dan Prasarana Di Smk N 1 Kasihan Bantul. Jurnal Akutabilitas Manajemen Pendidikan, 1(1), 98-108.

Megasari, R. (2014). Pendidikan Untuk Meningkatan Kualitas. Bahana Manajemen Pendidikan | Jurnal Administrasi Pendidikan Halaman, 2(1), 636-648.

Mirna Santi, A. P. (2018). Analisis Implementasi Ujian Nasional Berbasis Komputer. Cyberspace: Jurnal Pendidikan Teknologi Informasi, 2(2), 84 91.

Mohammed, A. K., \& Ahmed, A. (2014). ELearning Environment with Problem Solving Places for Teaching and Learning of Algorithm Oriented Concept s. In International Conference on Control, Instrumentation, Communication and Computational Technologies (ICCICCT) E-Learning (pp. 17-20).

Naldi, H. (2019). Urgensi Pengelolaan Pembiayaan dalam Upaya Meningkatkan Kualitas Pendidikan di Madrasah. Pedagogi: Jurnal Ilmu Pendidikan, 19(2), 105-113.

Rahmawati, F. (2014). Pengaruh Strategi Information Search (Is) Dan Learning Start With A Question (Lsq) Terhadap Hasil Belajar Siswa Kelas Viii Semester
Genap Smp Negeri 26 Bandar Lampung. LENTERA, 2, 139-148.

Rahmiyati, S. (2008). The Effectiveness Of Laboratory Use In. Jurnal Penelitian Dan Evaluasi Pendidikan, 1(9), 88-100.

Rasyid, M. (2014). Pengaruh Pemberian Kuis pada Pembelajaran Kooperatif Tipe Numbered Head Together ( NHT ) Terhadap Hasil Belajar Kimia Siswa Kelas XI IPA SMA Negeri 2 Pangkajene ( Studi Pada Materi Pokok Larutan Asam Basa) The Effect of Quiz on Numbered Head Together ( N (pp. 85-91).

Reni Ernawati, E. a. (2016). Penerapan Model Pembelajaran Aktif-Kooperatif Tipe Lsa Terhadap Peningkatan Hasil Belajar Siswa Sma Pada Subkonsep Sistem Imun Manusia. Jurnal Pendidikan Guru Sekolah Dasar, 11(1), 90-109.

Risi, M. (2018). The importance of interaction mechanisms in blended learning courses involving problem solving. In 2018 Thirteenth International Conference on Digital Information Management (ICDIM) (pp. 124-129). IEEE.

Rizal, M. S. (2018). Pengaruh Model Pembelajaran Kooperatif Tipe Think Talk Write (Ttw) Terhadap Keaktifan Dalam Pembelajaran Ips Kelas V Sdn 020 Kuok. JURNAL BASICEDU, 2(23), 111-119.

Santosa, T. A., Sepriyani, E. M., \& Razak, A. (2021). Analisis E-Learning Dalam Pembelajaran Evolusi Mahasiswa Pendidikan Biologi Selama Pandemi Covid-19. EDUMASPUL, 5(1), 66-70.

Simatupang, A. C., \& Sitompul, A. F. (2013). Analisis Sarana Dan Prasarana Laboratorium Biologi Dan Pelaksanaan Kegiatan Praktikum Biologi Dalam Mendukung Pembelajaran Biologi Kelas Xi. JURNAL PELITA PENDIDIKAN, 6(2), 109-115. 